\title{
EXTENSION AND SUSTAINABLE DEVELOPMENT IN GLOBALIZATION CONDITIONS
}

\section{Kudinova Iryna}

National University of Life and Environmental Sciences of Ukraine, Kyiv, Ukraine

\section{ДОРАДНИЦТВО ТА СТАЛИЙ РОЗВИТОК В УМОВАХ ГЛОБАЛІЗАЦІї}

\section{Кудінова Ірина}

Received 15. 6. 2017
Revised 22. 6. 2017

The theoretical aspects of sustainable development are considered in the article. Its essence and features are exposed in the agrarian sector of economics. It is well-proven that sustainable development of territory depends on sustainability of economic, social and ecological factors and sent to satisfaction of necessities present and future generations. The Extension service (informatively-consultative) of sustainable development of agriculture is reasonabled. The primary objective of sustainable development of territory is providing of accumulation of resource possibilities for realization of the extended recreation and increase of level of welfare of population without harm to the environment. Creation of research and information centers and scientifically-educational establishments is offered on questions sustainable development and centers of the best practices of sustainable development.

Keywords: extension; sustainable development; information and consultation providing; agriculture

\section{Вступ}

Проблема досягнення сталого розвитку держави в умовах посилення глобалізаційних викликів набуває особливої уваги. Сталий розвиток $\epsilon$ новою світоглядною, політичною та практичною моделлю розвитку для усіх країн світу, які розпочали перехід від суто економічної моделі розвитку до пошуку оптимального балансу між трьома складовими розвитку - економічною, соціальною та екологічною. Реалізація цієї моделі потребує формування системи публічного управління сталим розвитком, необхідною передумовою якого та його важливою складовою, $\epsilon$ належне дорадче забезпечення, що підвищує ефективність прийняття управлінських рішень. Метою нашої роботи було вивчення теоретичних підходів та практичних засад дорадчого (інформаційно-консультаційного) забезпечення сталого розвитку сільського господарства.

\section{Матеріали та методи}

Методологічною основою дослідження обрано системний підхід до вивчення процесів та явищ, за допомогою якого виявлені проблеми розглядаються з позицій цілісності і нерозривності об'єкта та середовища його існування, цілей і методів управління, засобів та інструментів моніторингу. 
Системний підхід дає можливість ідентифікувати проблемні аспекти сталого розвитку та його дорадчого забезпечення.

Проблеми розвитку дорадчої діяльності досліджуються протягом тривалого часу. Їх вирішенню присвятили свої праці відомі вчені: М.Ф. Кропивко, Т.П. Кальна-Дубінюк, М.Ф. Безкровний, Л.Х. Рибак, В.А. Верба, Т.І. Решетняк та інші дослідники. Однак, актуальність представлених питань та їхнє недостатнє науково-методичне забезпечення потребують розвитку досліджень.

\section{Результати та їх обговорення}

Сільськогосподарське дорадництво на сьогоднішній день відіграє велике значення у розвитку сільських територій у цілому. Сільськогосподарська дорадча діяльність спрямована на задоволення потреб сільськогосподарських товаровиробників і сільського населення упідвищенні рівняїхзнаньіувдосконаленніпрактичнихнавичокприбутковогогосподарювання, поліпшення добробуту селян і розвиток сільської місцевості.

Сільськогосподарське дорадництво почало формуватися на початку 2000-х років, а дістало своє правове закріплення у Законі України "Про сільськогосподарську дорадчу діяльність" від 17 червня 2004 р. Саме цей закон виокремив особливості правового регулювання дорадництва у сільському господарстві.

Проведений аналіз економічної літератури показав, що дорадництво - це нове економічне явище, яке має на меті відродити сільське господарство та забезпечити його стабільний, сталий, прибутковий розвиток, на основі специфічних методів (підвищення рівня знань та практичних навичок на основі активних методів навчання; забезпечення найновішою інтегрованою інформацією з різних сфер буття; індивідуальними практичними порадами, демонстраційними показами), формувати нового селянина з новим типом економічного мислення, новою ринковою мотивацією та поведінкою і надає можливість цим ключовим факторам прогресу формувати нове сільське виробництво і нове село.

Дорадча освіта залучає свідоме використання і розповсюдження інформації, щоб допомогти людям формувати вірні погляди та приймати потрібні рішення. Консультування $\epsilon$ ефективним інструментом тільки коли комбінується 3 іншими, такими як дослідження, забезпечення ресурсами, кредитами, маркетингом (Кальна-Дубінюк, 2014).

Перехід сільського господарства України на засади сталого розвитку на сьогоднішній день $\epsilon$ вкрай необхідним, враховуючи його економічний, соціальний та екологічний стан.

В короткостроковій перспективі стратегічною метою сталого розвитку України повинне бути подолання економічної та структурної кризи, що розвинулись в період переходу до ринкової економіки та демократичного громадського суспільства. Для досягнення сталого розвитку $\epsilon$ необхідним комплексний підхід (Герман, 2007; Підліснюк, 2008):

екологічна безпека: стратегічна мета - збереження і відновлення природних екосистем, стабілізація та поліпшення якості навколишнього середовища, зниження викидів шкідливих речовин і т.д.;

економічна стабільність: метою $\epsilon$ створення соціально й екологічно ефективної економіки, що забезпечує гідний рівень життя громадян, конкурентноздатність продукції. Важливою цільовою настановою повинно стати забезпечення економічного розвитку переважно на вже освоєних територіях;

соціальне благополуччя: основною метою є збільшення середньої тривалості життя населення, планування родини та раціоналізація особистого споживання, поліпшення середовища існування людини, розвиток його соціальної активності, забезпечення рівних можливостей в одержанні медичної допомоги, соціальний захист уразливих груп населення. 
В довгостроковій перспективі акценти розвитку будуть зміщуватися з економічних на екологосоціальні та з матеріальних на духовно-моральні та інформаційні ресурси.

Необхідно зазначити, що саме розвиток дорадництва сприяє досягненню сталого розвитку агросфери. Науково-інформаційне забезпечення в реалізації ідей сталого розвитку агросфери має вирішальне значення (рис. 1).

\section{ДОРАДЧЕ ЗАБЕЗПЕЧЕННЯ В РЕАЛІЗАЦІЇ СТАЛОГО РОЗВИТКУ}

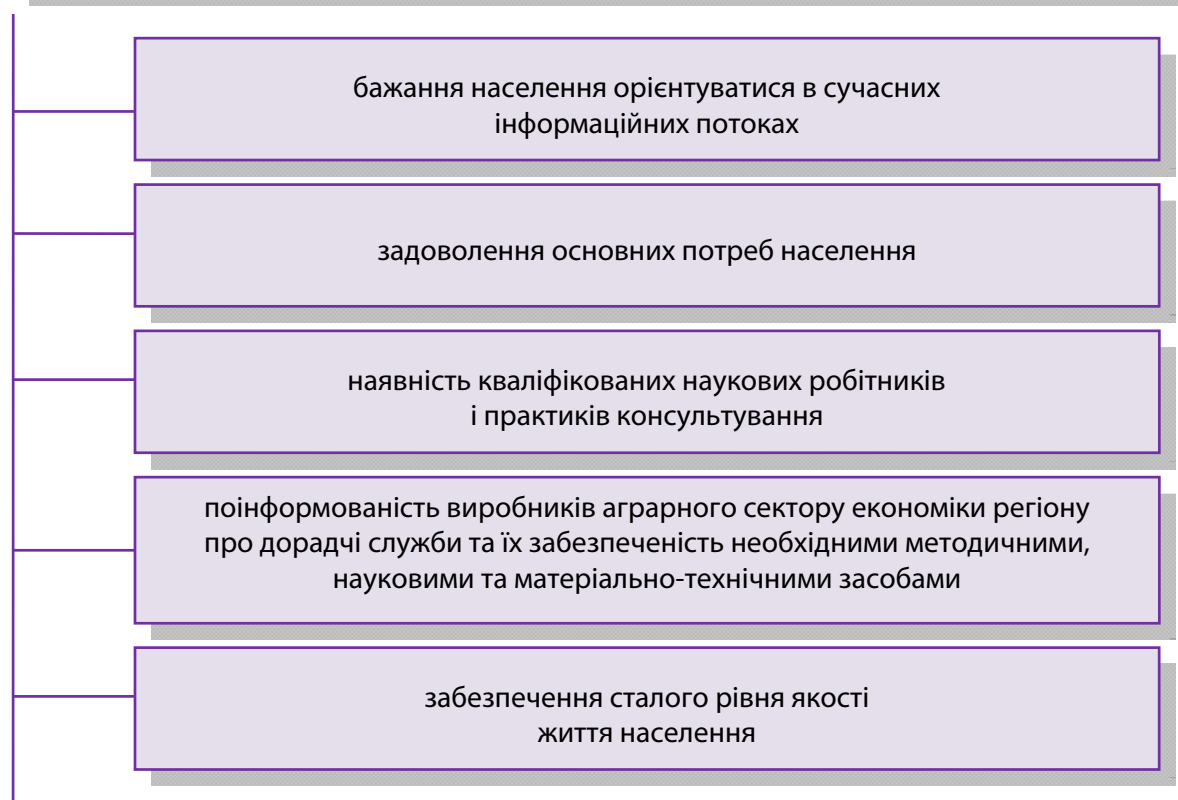

Рисунок 1 Дорадче забезпечення реалізації сталого розвитку

Figure 1 Extension providing of sustainable development implementation

Достовірна і повна інформація - необхідна умова розроблення та прийняття відповідних управлінських рішень у галузі раціоналізації та екологізації сільськогосподарського виробництва. Тому удосконалення потребує система державного статистичного спостереження та моніторингу, аудиту, експертизи природних об'єктів.

Дорадчі послуги передбачають поширення знань та інформації від того, де вони $є$ до того, хто їх потребує з метою впровадження досягнень аграрної науки у сільськогосподарське виробництво і підвищення професійного рівня суб'єктів управління природокористуванням та забезпечення сталого розвитку агросфери (Сокол, 2015).

Саме тому необхідно здійснювати послідовне впровадження інформаційно-комунікаційних технологій із забезпеченням їх загальнодоступності, інтеграції у традиційні сектори економіки та суспільного життя, інформатизації діяльності органів влади та самоврядування й формуванням засад електронного врядування для сталого розвитку.

На нашу думку, доцільним було $б$ створити систему об'єктивного інформування всіх зацікавлений сторін про політичні, економічні, соціальні та екологічні аспекти сталого розвитку України та світу, а також інформаційно-аналітичні центри та науково-освітні установи з питань сталого розвитку та центри кращих практик сталого розвитку. 
Стратегічне бачення сталого розвитку України ґрунтується на забезпеченні національних інтересів та виконанні міжнародних зобов'язань України щодо сталого розвитку. Такий розвиток передбачає:

- подолання дисбалансів, які існують в економічній, соціальній, екологічній сферах;

- побудову мирного та безпечного, соціального згуртованого суспільства 3 належним управлінням та інклюзивними інституціями;

- забезпечення партнерської взаємодії органів державної влади, органів місцевого самоврядування, бізнесу, науки, освіти та організацій громадянського суспільства;

- повну зайнятість населення;

- високий рівень освіти та охорони здоров'я;

- стан довкілля, який забезпечуватиме якісне життя та благополуччя теперішнього і майбутніх поколінь;

- децентралізацію та впровадження регіональної політики, яка передбачає гармонійне поєднання загальнонаціональних і регіональних інтересів;

- збереження національних культурних цінностей і традицій.

Найважливішими елементами регулювання сталого розвитку $є$ моніторинг та прогнозування факторів, що визначають загрози сталого розвитку. Метою моніторингу $\epsilon$ дорадче (інформаційне-консультаційне) забезпечення чіткого виконання функцій органів державного управління.

\section{Висновки}

Дорадча діяльність $\epsilon$ складною специфічною системою реалізації форм та методів управлінської, навчальної та консультаційної діяльності. Зважаючи на розширення інформаційного простору та розвиток новітніх технологій, попит на консультаційний сервіс постійно зростає. Особливої актуальності набуває дорадче забезпечення з реалізації ідей сталого розвитку, що забезпечує накопичення його ресурсних можливостей для проведення розширеного відтворення і підвищення рівня добробуту населення. Дорадче забезпечення проявляється у просвітницькій роботі серед сільського населення, зокрема, через створення навчально-консультативних центрів, дорадчих служб, розвиток проектів допомоги, запровадження циклів тематичних навчально-практичних семінарів щодо реалізації концепції сталого розвитку сільських територій, надання консультаційної підтримки сільським громадам у реалізації основних напрямів сталого сільського розвитку.

\section{Література}

Герман, Л.М. 2007. Шляхи впровадження сталого розвитку в сільському господарстві України та роль сільськогосподарського дорадництва. Збірник доповідей мастер-класу "Роль дорадчих служб у підвищенні рентабельності сільського господарства". К.: ТОВ “Норіта-Плюс". 142 с.

Кальна-Дубінюк, Т.П., Кудінова, І.П., Рибак, Л.Х., Мосіюк, С.І., Самсонова, В.В., Локутова, О.А., Корінець, Р.Я., Сокол, Л.М., Бесчастна, М.В. 2014. Формування та розвиток системи дорадництва в Україні. Ніжин. 332 с.

Підліснюк, В.В. 2008. Основи сталого розвитку. Кременчук, 124 с.

Сокол, Л.М. 2015. Дорадництво у забезпеченні сталого розвитку агросфери. Науковий вісник НУБіП України: Серія «Економіка, аграрний менеджмент та бізнес». К., вип. 211, № 1, с. 162-170. 